\title{
AN EVALUATION OF PERMANENT ESTABLISHMENT / DIGITAL NEXUS CONCEPTS IN THE E-COMMERCE FIELD AND TAXATION IN TERMS OF INCOME TAXES
}

\author{
Arif AYLUÇTARHAN ${ }^{1}$
}

\begin{abstract}
The business models are rapidly changing by the influence of globalization and technology. As an outcome of this transformation, new e-commerce business types requires new tax legislation in terms of both domestic and international tax laws.

In this study, efforts on the taxation (income and corporate tax) of the commercial activities in the form of e-commerce on the digital workplace is put forward. In addition, the discussions about new regulations are discussed. The study is also supported by the experience of tax inspection conducted by the author of this study. The main argument supported by the study is the need to reorganize related regulations and take into account the authority of source country taxation in the field of electronic commerce, since the fact that income is generated within the digital workplace not in physical workplace.
\end{abstract}

Keywords: Digital Nexus, Permanent establishment, e-commerce, OECD Double Taxation Treaty, Limited Taxpayer

JEL Code: H2O, H24, H25.

\section{Introduction}

The limit of the application of a country's tax laws is the borders of the country where the state's sovereignty right applies. In terms of taxes on income (income and corporate tax), the taxpayer is determined within the borders of the country and the subject of the tax is formed by following it. In terms of these taxes, due to domestic legislation, limited liability and full liability commence at this point. The main condition for limited and full liability is the settlement criteria. While the full taxpayers are taxed on a worldwide scale, the limited taxpayers who are not residents of the country are taxed only on the income obtained in the country. If the full taxpayer obtains income from another country, then the distinction is made between the resident country and the source country (the country of obtained income). After this point, the issue arises as the issue of international double taxation. The main point to be solved here is the dilemma that the resident country or the source country has the right to taxation.

In the case of international double taxation treaties, the resident country and the source country dilemma for business profits is resolved through the permanent establishment (or permanent representative). Accordingly, in the event that commercial earnings are obtained in the source country through the permanent establishment (or permanent representative), the authority to tax is given to the source country with limitation of income from the permanent establishment. Apart from this, the authority of taxation is the state of the resident country. The basis of this taxation model is based on the argument that the country in which the income (value) is created

${ }^{1}$ Asst. Prof. Dr., Department of Commercial Law, School of Business, İstanbul University, İstanbul, Turkey, arif.ayluctarhan@istanbul.edu.tr 
is the resident country. However, in the text of the double taxation model treaty, the permanent establishment concept is organized as a physical structure. The main reason why the permanent establishment is considered as a physical structure is that the conventional business approach requires a permanent facility.

While, there is a significant recognition of the permanent establishment in the national and international tax legislation, in today's practice, the meaning of the physical workplace has declined considerably in the fields of e-commerce. The importance of the physical workplace has decreased significantly, especially in service sales transactions (internet advertising, finance, logistics, news broadcast, cloud computing, participatory social networks, entertainment services, etc.). At this point, the concept of "digital nexus" was started to be discussed intensively. Despite the fact that the model treaty text has not been changed in the OECD side to this extent yet, however important discussions are being carried out in order to make a minimum taxation based on the digital workplace.

\section{Turkey Legislation / Limited Taxpayer In Brief}

Tax laws, like other laws, find their application within the sovereignty boundaries of the country(Özbalcı, 2007: 77).Therefore, due to the manifestation of sovereignty non-resident individuals and legal entities in Turkey are subject to tax on their income obtained from Turkey. The criteria for business profit is to have a permanent establishment or permanent representative in Turkey andthe profit should be achieved by means ofthese places or these representatives (PITL Art. 7-CITL Art.3).

\section{OECD Double Taxation Treaty Regulations For Business Profit}

OECD Model Double Taxation Treaty which Turkey is a party of,according to article 5 and 7, as a basis,business profit shall be taxed in the resident country. However, in the event that the activity is carried out through the workplace in the other source country, the source country shall have the authority to tax, limited to the earnings attributed to the workplace(Gelir Idaresi Başkanlığı, 2014).

For non-residents, the workplace (permanent establishment) determines the limits of the taxation authority in the source country. In the event that the country is a permanent representative with contractual authority, it is accepted that the company has a permanent establishment.Thus, the permanent representative is defined through the concept of permanent establishment.

\section{The Basis Of The Taxation Of Commercial Earnings And Discussions}

By means of this physical workplace in the country of origin, it is ensured to provide sufficient economic asset threshold in that country and tax is paid to this country due to this economic nationality.This economic nationality approach was introduced by a delegation of economists (Bruins, Einaudi, Seligman and Sir Josiah Stamp) commissioned by the League of Nations after the First World War(Bruins et al., 1923).

The economists who prepared the abovementioned report; In their assessment of the competence of taxation, they concluded that the importance of attaching great importance to the places where the business profit was created and the various physical places that contributed to it 
contributed to the creation of income.From this point of view, the concept of economic nationality was later included in the OECD model agreement.

In the last decade, the physical workplace (permanent establishment) requirement for the necessary and sufficient economic presence (for economic nationality) has become considerably controversial.The most concrete step of the current discussions was the 2013 report named"Addressing Base Erosion and Profit Shifting-BEPS" published in 2013 by the OECD, as request of the $\mathrm{G} 20$ leaders as a result of the negotiations in 2012.

In 2014 and 2015, two reports on the number 1 action, the full name of which is "Addressing the Tax Challenges of the Digital Economy", mainly focused on the permanent establishment under the most important measurement proposal(OECD, 2014, 2015).In this context, first of all, can the exceptions for auxiliary or preparatory actions be changed or even eliminated? The question has been emphasized.Secondly, the idea of adopting digital workplace (digital nexus) as well as the concept of classic physical workplace is emphasized.Third, the significant presence test has been emphasized beyond the digital workplace alternative(Caveltiet al., 2019).

It can be stated that there is still a great debate on the harmonization of the existing digitalized economic conditions and the framework treaty provisions.Besides, a complete consensus has not been achieved yet.

\section{Previous Tax Inspection Detections About The Issue}

The business model of a firm engaged in electronic commerce based on a previous tax inspection conducted by the author of this work is explained below.

\section{Company}

The company is a kind of vehicle Technology Company which provides passenger services to passengers and passengers in the system by taking advantage of the application services on smartphones.

Processes performed by the XXX electronic platform are carried out step by step as follows.

- The passenger starts the application that he has downloaded to his/her smartphone in advance and selects the address of the destination. The transport fare is shown to the passenger for the destination, the passenger sees this fee and calls the vehicle call option.

-After the journey is completed, the price of the gross transportation service is collected by XXX on the credit / debit card system on and sent to the Netherlands directly. $20 \%$ of the total amount is taken as a commission by XXX and the remaining $80 \%$ is transferred to the driver's account on weekly basis (total).

XXX 's does not have a central or branch in Turkey. The company offers passenger and driver services from the Netherlands. This company has not beensubjected to any tax assessment due to company's business model (not having any physical offices or representatives in Turkey). 


\section{Conclusion}

Technology and globalization are rapidly transforming the business world.Nowadays, digitalized products produced within the framework of new business models reach the customer in a place far from the physical workplace.Therefore, it does not seem fair and reasonable to limit the taxation authority of the source country to the physical workplace.Although a taxation method based on physical workplace and the taxation authority is given to the country where the company is a resident of the enterprise, it does not correspond to the current business models.

These conditions must be correctly analyzed and in accordance with the digitalized economy structure, the country tax legislation and OECD model treaty provisions should be directed to a demand-side approach from supply-side approach.In other words, the country where the end-consumer is located (source country) has to be more competent, not the country where the physical workplace is.

In this context, digital workplace and significant presence testing approaches can be considered as reasonable methods. In the new digitalized business models, the place of production of goods or services becomes less prominent, but since the demand for the same goods and services is more prominent, this place contributes more to taxable income.

\section{References}

Cavelti, Luzius U., Christian Jaag, Tobias F. Rohner "Why Corporte Taxation Means Source Taxation A Response to the OECD's Actions Against Base Erosion and Profit Shifting" https://www. bakermckenzie.com/en/-/media/files/people/rohner-tobias/24why-corporate-taxationmeans-source-taxation--a-response-to-the-oecds-actions-against-base-erosion-and-profitshifting.pdf. (01.04. 2019).

Bruins, Einaudi, Seligman \& Sir Josiah Stamp (1923), Report on Double Taxation submitted to the Financial Committee, No. E.F.S. 73.F.19, League of Nations, Geneva. http://adc.library. usyd.edu.au/view?docld=split/law/xml-main-texts/brulegi-source-bibl-1.xml;chunk. id=item-1;toc. depth=1;toc.id=item-1;database=;collection=; brand=default(15.02. 2019).

Gelir İaresi Başkanlığı, OECD Model YorumKitabi, "http://www.gib.gov.tr /sites/default/files/ fileadmin/ user_upload/ Mevzuat_Dis Iliskiler/OECD_Model_Yorum_Kitabi_2014.pdf). (15.02.2018).

OECD. (2014). Addressing the Tax Challenges of the Digital Economy, Action 1 - 2014 Interim Report https://www.oecd.org/ctp/addressing-the-tax-challenges-of-the-digital-economy9789264218789-en.htm. (01.04. 2019).

OECD. (2015). Addressing the Tax Challenges of the Digital Economy, Action 1-2015 Final Reporthttps:// www.oecd-ilibrary.org/docserver/9789264241046en. pdf?expires $=1550256936 \&$ id =id\&accname =guest \&checksum= BC4CDC02CE24EA8D2E3D25CBEA747670. (15.02.2018).

Özbalcı, Yılmaz (2007). Gelir Vergisi Kanunu (Yorum ve Açıklamaları), Ankara, Oluş Yayınları. 


\title{
EXAMINATION OF TAX ADMINISTRATION BY DIGITALIZATION: TAXATION OF SHARING ECONOMY; COUNTRY EXAMPLES AND EVALUATION OF TURKEY
}

\author{
Burçin BOZDOĞANOĞLU1
}

\begin{abstract}
The sharing economy or collaborative economy is a new economic model that uses online platforms to share individuals' assets, resources, time and capabilities on a scale that was not previously possible. There is no clear consensus among international economic institutions on its definition.Service providers, users and platforms that bring them together are the sides of this economy.Airbnb, Uber, Taskrabbit are the platforms created by this new economic model.

The fact that the sharing economy is a functioning economy through online platforms makes it difficult to evaluate within the framework of tax and legal regulations such as traditional economy.In order to determine whether the income obtained from the sharing economy is a primary or ancillary source of income, to clarify the tax obligations, to clarify the status of the parties involved in the sharing economy transactions and to ensure efficiency in the taxation, an approach that is not an 'one-size-fits-all' approach should be adopted, but according to each event and on a tax basis.

In this study, taxes, which are the subject of sharing economy which is a new economic model, and cooperation with platforms and determination of taxpayer awareness will be included.Models and practices for increasing awareness of the taxpayers implemented in cooperation with the platforms of the sharing economy taxation in the EU countries will be examined further assessment will be made regarding the size of the economy and taxation in Turkey.
\end{abstract}

Keywords: Sharing Economy, Taxation, Digital platforms, Tax compliance

JEL Code: H2, H24, K34.

\section{Introduction}

The sharing economy is technology applications that allow individuals to share goods and services through information and communication technologies, internet platforms, and are also known to the user as "peer to peer economy" or "collaborative economy".The sharing economy, which has begun to be seen in the last few years, is an economic model that enables the emergence of new platforms that allow the production and consumption of goods and services.

The Uber, Airbnb, TaskRabbit platforms within the sharing economy provide the possibility of renting a variety of services on a daily or hourly basis, including driving, renting, or using personal skills from other users through a personal computer or mobile application for their payment to consumers.

At this point, these economic models, which are based on individuals making agreements on the internet to share the assets or skills they possess, significantly affect the enterprises operating

1 Assoc. Prof., Bandırma Onyedi Eylul University, Public Finance Department, burcindogan@gmail.com 
in traditional commercial structures such as taxis, limousine services and hotels. For this reason, the concept of sharing economyshould be made in terms of new legal arrangements, whether the flexibility or changes in existing regulations should be ensured, the new regulations or changes will be made, how these will be done and propose the agenda for how can be the proper relationship between technological arrangements and technological reforms.

First of all, the concept of sharing economy will be tried to be defined especially in the context of international literature. In the second part of the study, the parties operating in the sharing economy will be explained and the cooperation platforms, which are the most important actors in terms of taxation, will be included on sectoral level. In the third part of the study, the size of the sharing economy, the taxes it is the subject and the taxpayers of these taxes will be mentioned. In the fourth chapter, the importance of cooperation with platforms in the taxation of the sharing economy and the related country practices are included. In the last part of the study, data and evaluations concerning the taxation of the economic model of the size of the sharing economy in Turkey is evaluated.

\section{The Concept Of Sharing Economy}

The phenomenon of sharing economics, especially in the media and in the academic literature, which has shown a significant growth since the crisis of 2008, attracts much attention as an umbrella concept, whose borders are still blurred.

In its decisions of September 2015 and October 2015, the European Parliament announced the sharing economy as follows: "the sharing economy, or collaborative consumption, is a new socio-economic model that has taken off thanks to the technological revolution, with the internet connecting people through online platforms on which transactions involving goods and services can be conducted securely and transparently" (EPRS,2016b:3).

The term "collaborative economy" refers to "business models where activities are facilitated by collaborative platforms that create an open marketplace for the temporary usage of goods or services often provided by private individuals" (EC, 2016:5).

\section{Parties of Sharing Economy}

According to the European Commission, the actors involved in the sharing economy can be classified in three categories. (EPRS,2016a:6) :

-Service providers sharing assets, resources, time, and skills: these may be private individuals serving at regular periods (peers) or professional service providers

-Users of services offered by service providers,

-collaborative economy platforms that connect providers with users and facilitate transactions between them, also ensuring the quality of these transactions e.g. through after- sale services (handling complaints), insurance services, etc. 


\section{Evaluation of the Value Created by the Sharing Economy and It's Taxation}

\subsection{Services Offered in the Sharing Economy and Estimated Economic Value}

The rapid change in technology, the economic crises experienced, the change in consumer models in the business world, changing the consumption models and acting with environmental concerns, led many people to search for different sources of finance and shopping and changing the way they made holidaysThe five sectors with the most activity in the sharing economy and the platforms in these sectors (with high economic value) are listed as follows. (EPRS,2016b:4):

-transportation ( Uber, BlaBlaCar),

-retail ( Etsy, eBay),

-accomodation (Airbnb, ShareDesk),

-service and labour (TaskRabbit, Shareyourmeal, Elance),

-finance (Kickstarter, Kiva, Indiegogo),

Annual growth rate of the share economy exceeds 25\% (EPRS,2016b:4). In 2016, the size of the sharing economy was 26.5 billion Euros.

\subsection{Determination of Taxes and Taxpayers on the Sharing Economy}

Since a number of transactions are conducted in tripartite relations through a platform, each taxpayer and each tax case must be considered separately.This situation will result in an obligation related to income tax and VAT if the revenue obtained exceeds a certain threshold.

Platforms can act as intermediaries and undertake legal responsibility for the collection of income in this activity. This may lead to concerns similar to the concerns of B2C platforms in the sharing economy, their size and tax implications caused by other multinational companies. (EPRS, 2018:18).

In this context, personal income tax is to be considered as a tax that must be taken into consideration for the services provided by service providers. If the supplier conducts its activities within the framework of its own personal capacity, the income earned by the individual supplier is included in the income tax base. (EPRS,2018:19). When the supplier operates within a business, it no longer falls under the subject of income tax.Both the service providers and online platforms in the sharing economy are, in principle, subject to indirect taxes starting with VAT obligations.

\section{The Role of Cooperation with Platforms in the Taxation of Sharing Economy and Country Applications}

\subsection{Role of Cooperation with Platforms}

The fact that all transactions on a platform where data is recorded, leaving digital traces allows the platforms to report these operations objectively. This provides the possibility to benefit from technology to improve tax management and frees sharing actors from monitoring a large number of small-scale P2P participants, especially small providers and self-employed. 
(EPRS,2018: 22).This also prevents a potential tax mismatch on behalf of small businesses and avoids the administrative burden of taxation (Aqib\&Shah,2017: 26).For this reason, the first step regarding tax obligations is to increase the awareness (P2P) for individuals acting as service providers, especially on sharing economy platforms.Basically, P2P providers serving as failures are not naturally experienced in required tax record-keeping and filing obligations (Rahim et al, 2017: 453). If tax is collected by the Platform and if record keeping is supported by information technologies reporting from the sharing-based economic platform, some of the administrative burden will be alleviated. At this point, the most fundamental requirement is to determine the threshold at which the service provider determines the tax payer.

\subsection{Country Applications}

In the EU, some countries have taken various measures to promote tax compliance in the sharing economy.

In France, the tax return form, known as 'automatic reporting of revenues for online platforms', and a number of information elements for each user responsible for taxation, are attached directly to the tax statement.In this tax declaration, a copy of the information per user is sent to the relevant user by online(OECD,2018:98).

A system established in Estonia, in September 2015 and since February 2016, allows drivers to register with a system where the transaction between service providers and the user is recorded by the platform. The platform then sends the information to the tax office about the income generated by the drivers involved in the ride-sharing system, which are automatically added to the tax returns based on the advanced online tax system (OECD,2018:99).

In the Netherlands, an agreement was signed between the Amsterdam city administration and Airbnb in 2014, requiring the platform to collect the city's tourism tax on behalf of service providers (EPRS,2016a: 161). Airbnb has been the pioneer of this model by transferring the tourist taxes that constitute $5 \%$ of the accommodation fee and transferring them to the state, in this model, where the homeowners also pay tourist tax (determined as $\% 5$ of the accomodation price) as well as the tax they will pay for the short-term lease.

\section{The Value Created by the Sharing Economy in Turkey and it's Evaluation in the Terms of Taxation}

\subsection{The Size of Sharing Economy in Turkey}

There is no research in the European Commission or the OECD level about the size of the sharing economy in Turkey. This new economic model, most current data about Turkey, contained in the report by PWC carried out the market research instititue Faktenkontor $\mathrm{GmbH}$ between June and August 2017 and based on a survey which represents on over 4500 consumersfrom six countries including Turkey and Austria, Belgium, Germany, the Netherlands, Switzerland (PWC,2017: 5).

Sharing economy throughout the year among the countries surveyed, with expenditure amounting to 1,031 euros per person to use Turkey realized the highest average spending (PWC,2017:6).

The estimated size of the market share in Turkey's economy is 38.3 billion euros. 


\subsection{The Taxes which are Sharing Economy Subject to in Turkey}

In Turkey, service providers and platforms as a player of the sharing economy actions are evaluated in framework of income tax, value added tax and corporation tax. Income Tax Law Article 37 deals with the income generated from commercial activities without the definition of commercial activity and is considered to be commercial gain.Given that commercial activities are carried out within a commercial organization based on continuity, based on the combined use of labor and capital, and activities in the sharing economy are evaluated within this framework, it is clear that if the activity includes a "continuity" component for the service providers, it will be considered as commercial gain. However, there is no explicit regulation as to how long a period of time for which activity is to be considered as the time period of continuity. This situation makes it difficult to determine what gain component will be affected by the activity.

When the provisions of the income tax related to income from immovable property are evaluated in the context of sharing economy; "for the benefit of the economic assets left for use by others", the income tax law under Article 70 can be accepted as income from immovable property.

In the event that the activities are evaluated within the scope of commercial earnings, VAT will be born as delivery / service will be deemed realized. However, delivery and services shall not be subject to VAT in case of incidental commercial activity.

On value added tax against the state of the platform that mediates the sharing economy in Turkey, Law No. 7061, an arrangement was made within the framework of law VAT added to the stipulation of Article 9. The provision in question as follows; "In so far residence in Turkey, the workplace, the legal center and business center value-added tax on real people who are not payers of value added tax by not regarding the services offered electronically paid shall be declared by those who offer this service. Ministry of Finance is authorized to determine the scope and principles and procedures of the services provided by electronically".

Pursuant to the aforementioned communiqué, service providers declare the Value Added Tax related to these transactions electronically with the VAT declaration no. 3. However, before this declaration, the form prepared by the tax administration shall be filled out electronically and accordingly a special VAT liability shall be provided to the Electronic Service Providers on behalf of the service provider in the Big Taxpayers Tax Office(Kara,2018). Considering the regulations made in terms of VAT with both the law and the communiqué, it is understood that legislation applications may face problems in the face of digital economy.

Namely; these institutions shall issue a VAT Declaration No. 3 within the framework of the said regulations, in the event they regulate commission invoices for the transactions they mediate. First of all, invoice arrangements will not be possible for service providers that do not have VAT liability. In addition, considering the fact that the platforms which are in the limited taxpayer category and which mediate the services have calculated the commission price on the basis of the transactions they mediate, the price in the commission invoice for the intermediary will be at the discretion of the platform since there is no invoice in accordance with the legislation.

Therefore, although the target capture system to digitalize said, this economic model cooperation arising from the taxable value through processing platform that can point to is of critical importance for Turkey. Because the provision and the applicability of the VAT declaration and the provisions added in Article 9 of the VAT Law depend on this cooperation to a large extent. 


\section{Conclusion}

The sharing economy, which is a relatively new phenomenon, has recently become widespread in some areas of activity such as ride-sharing or short-term rentals. Although it is now a wellknown term - from sharing to peer-to-peer economy, it refers to cheap access to information on a very large scale through a digital platform that meets supply and demands beyond the central feature to which potential consumers and providers are connected. The platforms that play an important role in the development of this economy make it possible for non-professional service providers to offer goods and services in a wide variety of areas, to generate value and to develop more development potential.

The sharing economy covering these situations is a rapidly developing phenomenon. However, the names used to describe this phenomenon, in particular, blur the lines with the use of the new three concepts: traditional consumer, business and 'user-provider-platforms' that do not match the agent concepts. Moreover, the regulatory frameworks on which the legal provisions to be used for their implementation are based do not contain clarity.Three-sided transactions cover a wide range of applications, from non-monetary sharing to real person businesses, and in particular from business to consumer (B2C) business models. In this context, this new digital economic model raises the need to make some market arrangements, including taxation.

In order to determine the tax requirements that arise in this new digital economic model, an approach that is appropriate to each event and a tax-based approach should be adopted, not an approach that fits all, in order to clarify the situation of the parties involved in the sharing economy transactions and to ensure efficiency in taxation.

Based on the existing examples of national and local regulatory approaches adopted so far, it may be possible to create alternative and operative solutions that are specific to some areas in which the sharing economy is developed and which address the defined side effects.Collaborating with platforms to ensure tax compliance of participants is one of these alternatives. Platforms may play a role in co-operation with tax authorities to exchange information on tax obligations. They can help with the tax statement process and may even take on the role of collecting some taxes (such as local taxes on tourism) by simplifying the collection of tax authorities.

It is the first step to clarify the definitions to address the tax challenges of the sharing economy, to comprehend the rapidly developing, multifaceted reality and to understand exactly what the sharing economy means. Arrangements made for the electronic service providers for Turkey in the understanding of the economic value created by this new digital models includes some difficulties in practice. It may be possible to overcome these difficulties in cooperation with platforms by taking into account the implementation examples in EU countries. 


\section{References}

Aslam A. \& Shah A. (2017), "Taxation and the Peer-to-Peer Economy", IMF Working Paper, August 2017, https://www.imf.org/ /media/Files/Publications/WP/2017/ wp17187.ashx, (02.07.2018)

European Parliament Research Service (2018), "Colloborative Economy and Taxation", February 2018, http://www.europarl.europa.eu/RegData/etudes/IDAN/2018/ 614718/EPRS_IDA(2018)614718_EN.pdf, (07.08.2018)

European Parliament Research Service (2016a). - The cost of Non-Europe in the Sharing Economy, European Added Value Unit of the Directorate for Impact Assessment and European Added Value, http://www.europarl.europa.eu/RegData/etudes/STUD /2016/558777/EPRS_STU(2016)558777_EN.pdf , (01.06.2018)

European Parliament Research Service (2016b). - A European agenda for the collaborative economy, Briefing, November 2016,http://www.europarl.europa.eu/RegData/ etudes/BRIE/2016/593510/EPRS_BRI(2016)593510_EN.pdf,

European Commission (2016). - A European Agenda for the Collaborative Economy, Brussels,https://ec.europa.eu/docsroom/documents/16881/attachments/2/translations/ en/renditions/pdf,

European Commission (2018), "Study to Monitor the Economic Development of the Colloborative Economy in the EU", http://www.technopolis-group.com/wp-content/uploads/2018/08/ CE_Final-report_PartA_Final_230218.pdf , (20.09.2018)

Kara M.S. (2018), "Elektronik Ortamda Sunulan Hizmetlerde KDV (3 No'lu KDV Beyannamesi)", Yaklaşım, Aralık 2018, Sayı:312, www.yaklasim.com

OECD (2018), Tax Challenges Arising from Digitalisation-Interim Report 2018 OECD/G20 Base Erosion and Profit Shifting Project, https://read.oecd-ilibrary.org/taxation/tax-challengesarising-from-digitalisation-interim-report_9789264293083-en\#page1 , (02.01.2019)

Özdemir M. (2019), “Elektronik Ticarette Aracılık Hizmetlerinin vergisel Açıdan Değerlendirilmesi”, E-Yaklaşım, Ocak 2019, www.yaklaşim.com

PWC (2017), Share Economy 2017 the New Business Model, https://www.pwc.de/de/digitaletransformation/share-economy-report-2017.pdf , (07.08.2018)

Rahim N. et al., Research on the sharing economy, Her Majesty's revenue and customs (HRMC)'s report, May 2017. 